\title{
The People and CRM (Customer Relationship Management)
}

\author{
Manish Roy Tirkey \\ Assistant Professor Joseph School of Business Studies, SHIATS Allahabad
}

\begin{abstract}
The evolution of Technology and its involvement in our everyday life has powerful implication for the relationship between government and citizen. Technology has the potential to completely transform the way government do business and how citizen relate to elected official and public agencies. At a minimum, today's constituent relationship management (CRM) technologies (telephony, Web systems, etc.) create the possibility for increased efficiency and effectiveness of government. More significantly, these tech- nologies can allow citizens to interact with government officials and staff in more mean- ingful and civically productive ways. With the rapid use of the Internet and its increased use by citizens for information and government data (reports on initiatives, types of services offered, etc.), online customer transactions and inquiries are becoming an increasingly important communication mode.
\end{abstract}

Keywords: CRM, Web System, Technologies, Government.

\section{Introduction}

It is far more expensive to acquire new customers than it is to retain existing customers.Instead of treating all customers equally; it is more effective for companies to invest in customers that are valuable or potentially valuable, while limiting their investments in nonvaluable customers. They expect to be served according to their individual and unique needs. Companies need to develop and manage their relationships with their clientele, because those relationships are profitable and create loyal customers.

Customer Relationship Management (CRM) includes all kind of interaction a company has with its customers, such as the strategies, processes, people and technologies in order to attract and maintain customers for maximum corporate growth and profit.(indiaweb) CRM can mean either relationship marketing or customer Management depending on the connection. CRM collects stores and analyse customer information, like demographics and future needs, with the help of methodologies, software, and usually Internet capabilities. (Balanced scorecard). Computers have changed the way companies are approaching their CRM strategies because it has also changed consumer buying behavior. CRM means also an enterprisewide integration of technologies working together such as data warehouse, Web site, intranet/extranet, call centers, accounting, sales, marketing and production. It has many similarities with ERP, but CRM is more like a frontoffice tool and CRM usually requires access to the back office data often through an ERPsystem. (Indiaweb)

\section{CRM, Government Accountability, and Trust}

In a CRM environment, governmental agencies are pressed to provide quality services with measurable results. In a environment, this accountability is focused not only on the call-taker who responds to the citizen inquiry/request for service, but also on the em- ployee(s) who are responsible for resolution of the citizen's call. In organizations that have embraced CRM disciplines, it is not acceptable for callers to have to wait inordinate amounts of time to have their calls answered and receive an answer/resolution to their question/problem, or to speak to a representative who is not polite or actively seeking res- olution to the caller's concerns. This is the foundation of what CRM provides to constitu- ents.

Citizens must be assured that their inquiry will be handled appropriately. To do this, gov- ernments can provide callers with a tracking number so that they may check on the status of their request by phone or via Web if the government has made this information avail- able online. One of the by-products of accountability is an increased level of trust in government. By tracking the status of complaints/inquiries and ensuring the expeditious resolution of the problem, governments are poised to enhance the trust that citizens have in government For constituents, the satisfaction with their CRM experience will be directly related not only to the likelihood that they will again utilize these services, but also to their overall satisfaction with governmental services in general. 
Exhibit 2.1 depicts this relationship.

\section{Exhibit 2.1: How CRM Satisfaction Affects Trust in Government}

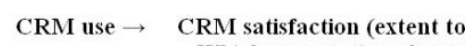

\section{CRM and Government Effectiveness}

CRM increases the effectiveness of government. "Effectiveness" refers to government's ability to achieve service goals and objectives. This directly relates to the amount of time that lapses before citizens receive a resolution to their call/request. By consolidating the citizen inquiry and response monitoring process into a CRM contact center, it is possible for management to assess any overlap that exists between agencies' services as well as the overall ability of an agency to provide the required services. One of the central features of CRM is the ability to track incoming calls by service type and status, and to monitor agency progress in responding. By providing management with a performance report on the number of days required to respond to certain types of calls (i.e., pothole filling), staff are able to assess the government's ability to respond to the citizen's request (i.e., to fill the pothole). Failure to perform according to defined stan-dards highlights the need for further investigation into the root causes of under- performance. For instance, it is possible that a delay is due to the fact that the material required to fill the pothole is unavailable because of a problem with a purchasing contract (procurement department), the number of trucks available due to mechanical problems (fleet management), or the number of staff available to work on the request (personnel department). Through CRM, management is able to close the loop on accountability by identifying the exact point where service is breaking down and dedicate the resources nec- essary to eradicate the problem. By resolving the issue, managers are increasing the effectiveness of governmental operations. Citizens benefit from CRM technology because relevant, timely data is put in the hands of the decision makers - those with the ability to overcome institutional problems that frustrate an expeditious resolution of the constituent's request.

\section{CRM and Government Efficiency}

Probably one of the most quantifiable benefits of CRM is increased efficiency. Most nota- bly, efficiency improvement comes from the routing of service calls to the most appropri- ate party. The most prevalent example of this is when the government's emergency sys- tem becomes more efficient by diverting non-emergency calls that could impede the city's emergency response. Further, by consolidating call intake governments are able to reduce the number of duplicate deployments for the same service : CRM programs allow call-takers to identify that calls made by two separate citizens are for the same service request. Eliminating these redundancies can provide significant taxpayer savings.

\section{Conclusion}

While implementing CRM technologies in government requires thoughtful planning and considerable resources, the payoff to the citizen (and, ultimately, the government) is immense. By becoming more constituent-focused in its operations, a government is poised to dramatically affect citizens in the following ways:

- By providing a single point of contact through a CRM contact center, citizens are able to hold government accountable for the services that it is charged with performing. Inevitably, this interaction will affect the citizens' satisfaction with government services and, ultimately, their trust in government.

- By monitoring and evaluating efforts to address constituent problems, governmentsensure that they become increasingly responsive to citizen inquiries, respond to problems more expeditiously, and enhance the overall effectiveness of government.

- Via consolidation of service request intake, governments are able to reduce redundancies and better coordinate resources.

\section{References}

[1] Chadwick and C. May, "Interaction between States and Citizens in the Age of the Internet: E-Government in the United States, Britain, and the European Union," Governance: An International Journal of Policy, Administration and Institutions 16, no. 2 (2003): 271-300.

[2] David Myron, "CRM.GOV," Customer Relationship Management (July 2004): 26-30.

[3] D. M. West, "E-Government and the Transformation of Service Delivery and Citizen Attitudes," Public Administration Review 64, no. 1 (2004): 15-27.

[4] Myron, "CRM.GOV," Customer Relationship Management.

[5] Modified from E. Welch, C. Hinnant, and J. Moon, "Linking Citizen Satisfaction with E-Government with Trust in Government," Journal of Public Administration Research and Theory 15 (2005): 371-191.

[6] M. Bovens and S. Zourdis, "From Street-Level to System-Level Bureaucracies: How Information and Communication Technology is Transforming Administrative Discretion and Constitutional Control," Public Administration Review 62, no. 2 (2002): 174-184.

[7] Yuhang Shi and Carmine Scavo, "Citizen Participation and Direct Democracy Through Computer Networking," in Handbook of Public Information Systems, G. David Garson, ed. (New York: Marcel Dekker, Inc., 2000), 247-263. 